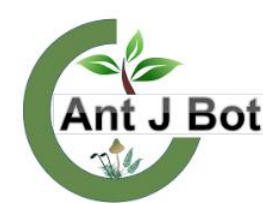

Received : 06.04.2020 Accepted : 01.05.2020 Online : $: 05.05 .2020$

\title{
Pericarp anatomy and surface micromorphology of some orchids in the Black Sea Region
}

\author{
Şenay SÜNGÜ ŞEKER ${ }^{1^{*}} \oplus$, Mustafa Kemal AKBULUT ${ }^{2} \oplus$ Gülcan $_{\text {SENEL }}^{3}{ }^{3 \oplus}$ \\ ${ }^{1,3}$ Ondokuz, Mayss University, Faculty of Arts and Sciences, Department of Biology, Samsun, Turkey \\ ${ }^{2}$ Çanakkale Onsekiz Mart University, Lapseki Vocational School, Department of Landscape and Ornamental \\ Plants, Canakkale, Turkey \\ *senay.sungu@omu.edu.tr, ${ }^{2}$ mkakbulut@comu.edu.tr, ${ }^{3}$ gsenel@omu.edu.tr
}

\section{Karadeniz bölgesinde yayılıs gösteren bazı orkidelerin perikarp anatomisi ve yüzey mikromorfolojisi}

\begin{abstract}
In this study, we have investigated the anatomy and ultrastructure of the pericarp to determine important characters of the fruits belonging to some Turkish orchidoid species, and to determine which features are related to ecological or habitat preferences. For the purpose, the samples belonging to 19 orchid taxon were collected in the Black Sea Region. SEM and light microscopy photographs were taken with the standard techniques. Variations among taxa were evaluated using various statistical methods such as correlation and discrimination analysis. Among the investigated characteristics, fruit surface ornamentation is related to habitat preferences of the species while morphometric properties of epidermal cells and structural features such as the type of crystal inclusions are important characters at the genus level
\end{abstract}

Key words: Anatomy, discrimination analysis, micromorphology, Orchidaceae, Orchidoidae

Özet: Bu çalışmada, bazı orkide türlerine ait meyvelerin önemli özelliklerini belirlemek ve hangi özelliklerin ekolojik veya habitat tercihleriyle ilişkili olduğunu tespit etmek için perikarp anatomisi ve mikromorfolojisi incelenmiştir. Bu amaçla, Karadeniz Bölgesi'nde 19 orkide taksonuna ait örnekler toplanmıştır. Standart tekniklerle SEM ve 1şık mikroskobu fotoğrafları çekilmiştir. Taksonlar arasında çeşitlilik arz eden özellikler korelasyon ve ayrım analizleri gibi çeşitli istatistiksel yöntemler kullanılarak değerlendirilmiştir. İncelenen özellikler arasında meyve yüzey desenlenmesi türlerin habitat tercihleri ile ilișkili iken epidermal hücrelere ait morfometrik özellikler ile kristal inklüzyonların çeşidi gibi yapısal özellikler cins seviyesinde önemli ayırt edici karakterlerdir.

Anahtar Kelimeler: Anatomi, ayrım analizi, mikromorfoloji, Orchidaceae, Orchidoidae

Citation: Süngü Şeker Ş, Akbulut MK, Şenel G (2020). Pericarp anatomy and surface micromorphology of some orchids in the Black Sea Region. Anatolian Journal of Botany 4(1): 69-75.

\section{Introduction}

Orchidaceae is one of the largest families in terms of biodiversity and is flowering plants with wide area of distribution excluding extreme habitats (Dressler, 1993). With more than 800 genera and nearly 27.000 species, new members are added to the orchid family every year (Chase et al., 2015; The Plant List, 2018). In Turkey, it is possible to encounter over 200 taxa from sea level to over 2000 m elevation (Davis and Davis, 1982; Güner et al., 2012). Additionally, the economic value of these plants is increased through widespread use in food, cosmetic and pharmaceutical industries (Sezik, 1984).

Structural studies of orchids have focused on flower parts generally due to the morphological variety and unrivaled pollination strategies of flowers (Stpiczyńska, 2003; Cozzolino and Widmer, 2005; Schiestl, 2005; Bell et al., 2009; Vereecken, 2009; Anton et al., 2012; Nunes et al., 2015). Furthermore, studies about the internal and surface structure of seeds rather than fruit, symbiotic-asymbiotic germination trials or orchid-fungus relationships are seen to be more notable (Gamarra et al., 2007; Chemisquy et al., 2009; Chen et al., 2012; Gamarra et al., 2012; Tesitelová et al., 2012; Bektaş et al., 2013). Though seeds are very small, they show high rates of variety in testa structure. The physical properties of seeds and the functional outcomes of these properties were revealed in detail by Arditti and Ghani (2000). Also, some studies have revealed the developmental features of seed coats (Molvray and Chase, 1999; Lee et al., 2005, 2007). Many micromorphological studies have stated that seed shape, surface patterning, anticlinal and periclinal wall structures or shape of testa cells are characteristic at different systematic categories and are reliable character to contribute to solving systematic problems in the family (Gamarra et al., 2012; Barthlott et al., 2014; Akbulut and Şenel, 2016; Şeker and Şenel, 2017; Gamarra et al., 2018).

The most accepted opinion related to developmental features of orchid fruit is that they comprise three carpels and the midvein of the carpel is located immediately below the stigma lobes. Orchids have marginal placentation (Brown, 1831; Payer, 1857; Van Tieghem, 1871). Additionally, according to the split-carpel model, the fruit is thought to occur by joining of other flower parts like sepal and petals. In this model, the sepals divide the carpels into two equal pieces and each petal joins to two separate carpel sections to form the fruit (Rasmussen and Johansen, 2006). In spite of detailed investigation of the internal structure of the carpel in these studies, the pericarpic surface morphology or morphometric features have been ignored compared to the seed.

Due to excessive number of species, high rate of variation in flowers or hybridization capacity, revealing characters rapidly and reliably for solutions to systematic problems carries great importance for orchids (Arditti, 1977; 
Dressler, 1993). Many problems have not been solved due to identification based on flower morphology. With the more common use of molecular markers in recent years, systematic categories of many species have changed (Bateman et al., 2003).

However, the main disadvantages of these methods are high cost and requirement for additional approaches to differentiate closely-related taxa. In this study, the aim was to determine distinguishing features for the pericarp of closely-related orchid species, identification of whether these features are useful for classification and research of the relationships with habitat and ecological preferences of taxa.

\section{Materials and Method}

Samples were collected from different localities in the Black Sea Region from 2012-2016 (Table 1). Species identification was completed using Flora of Turkey and Türkiye Bitkileri Listesi (Davis and Davis, 1982; Güner et al., 2012). Fruits were fixated in formalin-acetic acidalcohol (FAA) and then stored in 70\% ethyl alcohol.

Table 1. List of Orchidaceae taxa and localities.

\begin{tabular}{|c|c|c|}
\hline Taxa & Locality & Voucher \\
\hline Anacamptis laxiflora (Lam.) R.M.Bateman, Pridgeon \& M.W.Chase & Ondokuzmayis, Samsun & Ss,36 \\
\hline Anacamptis laxiflora & Terme, Samsun & Ss,37 \\
\hline $\begin{array}{l}\text { Anacamptis papilionacea (L.) R.M.Bateman, Pridgeon \& } \\
\text { M.W.Chase }\end{array}$ & Avdan, Canik, Samsun & Omuhb,7226 \\
\hline Anacamptis papilionacea & Kurupelit, Samsun & Omuhb,7827 \\
\hline Anacamptis pyramidalis (L.) Rich. & Kurupelit, Samsun & Omuhb,4141 \\
\hline Anacamptis pyramidalis & Avdan, Canik, Samsun & Omuhb,4142 \\
\hline Coeloglossum viride (L.) Hartm. & Köprübaş1, Trabzon & Omuhb,8253 \\
\hline Dactylorhiza euxina (Nevski) H.Baumann \& Künkele & Köprübaş1, Trabzon & Mka,15 \\
\hline Dactylorhiza euxina & Kavron, Rize & Mka,18 \\
\hline Dactylorhiza romana (Seb.) Soó & Kurupelit, Samsun & Mka,11 \\
\hline Dactylorhiza romana & Abant, Bolu & Ss, 10 \\
\hline Dactylorhiza saccifera (Brongn.) Soó & Ayder, Rize & Mka,19 \\
\hline Dactylorhiza saccifera & Köprübaş1, Trabzon & Mka,20 \\
\hline Gymnadenia conopsea (L.) R.Br. & Köprübaş1, Trabzon & Mka,27 \\
\hline Himantoglossum caprinum (M. Bieb.) Spreng. & Bayabat, Sinop & Mka,28 \\
\hline Himantoglossum caprinum & Kurupelit, Samsun & Omuhb,7739 \\
\hline Neotinea tridentata (Scop.) R.M.Bateman, Pridgeon \& M.W.Chase & Maraşl1, Çaykara, Trabzon & Mka,42 \\
\hline Neotinea tridentata & Kurupelit, Samsun & Ss,26 \\
\hline Neotinea tridentata & Fatsa, Ordu & Ss, 25 \\
\hline Ophrys apifera Huds. & Kurupelit, Samsun & Ss,39 \\
\hline Ophrys apifera & Avdan, Canik, Samsun & Omuhb,7716 \\
\hline Ophrys oestrifera M. Bieb. & Kurupelit, Samsun & Omuhb,7717 \\
\hline Ophrys oestrifera & Kavak, Samsun & Omuhb,7727 \\
\hline Orchis mascula $\mathrm{L}$. & Kurupelit, Samsun & Omuhb,7712 \\
\hline Orchis mascula & Abant, Bolu & Ss,16 \\
\hline Orchis mascula & Çambaşı, Ordu & Omuhb,7829 \\
\hline Orchis pallens $\mathrm{L}$. & Abant, Bolu & Ss,17 \\
\hline Orchis pallens & Köprübaş1, Trabzon & Mka,22 \\
\hline Orchis purpurea Huds. & Kurupelit, Samsun & Ss,14 \\
\hline Orchis purpurea & Fatsa, Ordu & Ss, 21 \\
\hline Orchis purpurea & Abant, Bolu & Ss, 22 \\
\hline Orchis purpurea & Kavak, Samsun & Ss,24 \\
\hline Platanthera chlorantha (Cruster) Rchb. & Kurupelit, Samsun & Omuhb,4123 \\
\hline Platanthera chlorantha & Kavak, Samsun & Mka,33 \\
\hline Serapias orientalis Greuter & Kurupelit, Samsun & Ss,35 \\
\hline Spiranthes spiralis (L.) Chevall & Kurupelit, Samsun & Mka,38 \\
\hline Spiranthes spiralis & Köprübaş1, Trabzon & Mka,49 \\
\hline Steveniella satyrioides (Spreng.) Schltr. & Kurupelit, Samsun & Omuhb,3041 \\
\hline Steveniella satyrioides & Ünye, Ordu & Mka,50 \\
\hline Steveniella satyrioides & Bafra, Samsun & $\mathrm{Mka}, 40$ \\
\hline
\end{tabular}

To determine the anatomical and morphometrical characters, cross-section and surface sections were taken from fruit samples from at least three different individuals in each taxon. Anatomical features were investigated using a light microscope (Zeiss AxioLab A1 microscope and the Zeiss Axiocam 105 imaging system) and morphometric features were assessed with at least 30 measurements for each character. Furthermore, pericarp surface micromorphology was identified with scanning electron microscope studies. Samples were passed though alcohol series $(30 \%, 50 \%, 70 \%$ and $95 \%)$ to remove excess water from tissues and dried with a critical point dryer. After coating with $15 \mathrm{~mm}$ gold-palladium (SEM coating system, SC7620), surface investigations were 


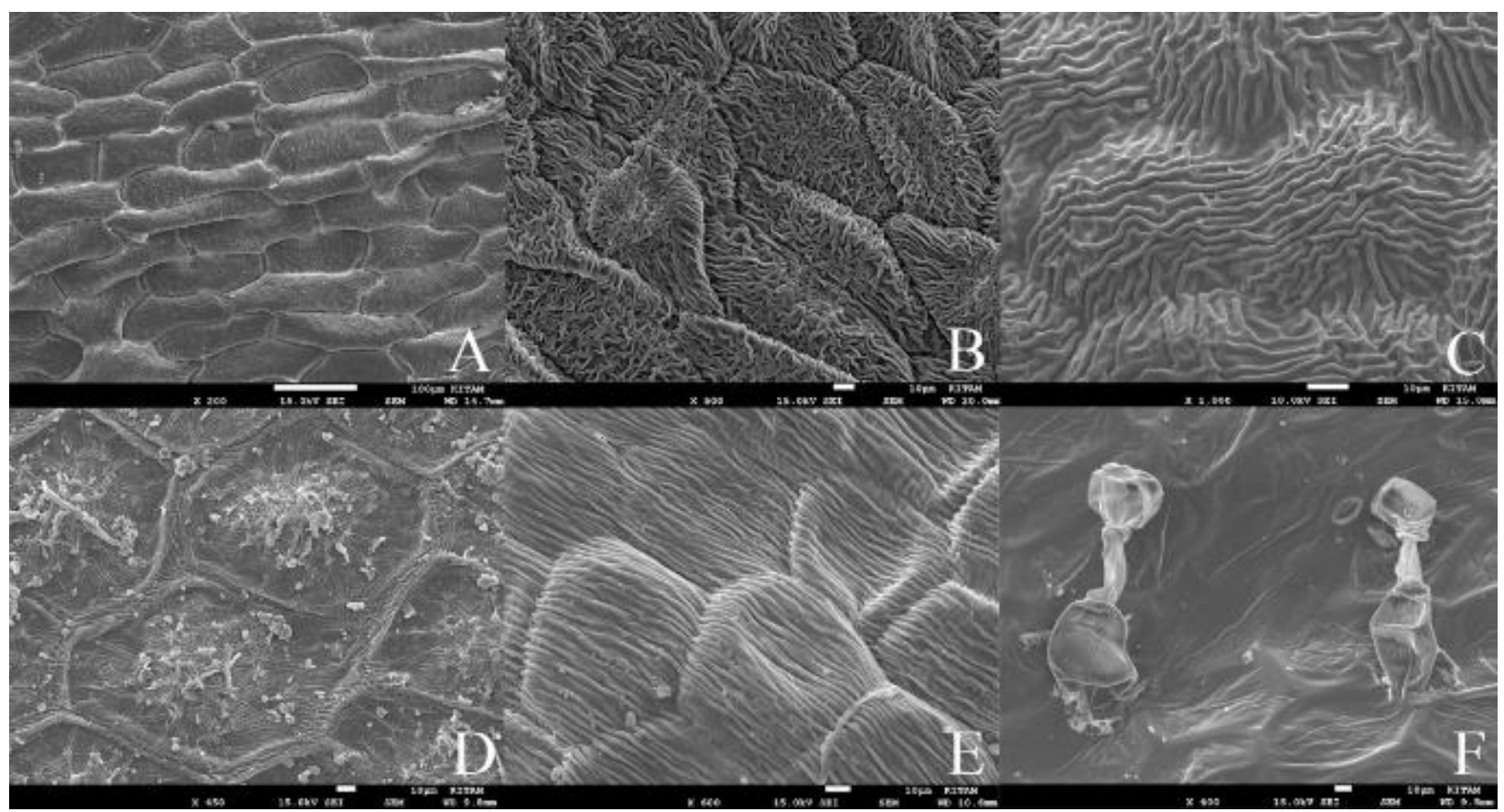

Figure 1. SEM image of the fruit surface: (A) H. caprinum, (B) S. orientalis, (C) O. pallens, (D) N. tridentata, (E) D. euxina, (F) S. spiralis.

completed with a JEOL JMS-7001F brand scanning electron microscope (SEM, 5-15 kV voltage). For organization of photographs the Photoshop CS6 program was used.

Correlation analyses were performed to assess the correlation between structural features and ecological or habitat preferences and ordination tests (CDA: canonical discrimination analysis) were used to identify the effect of characters on taxa differentiation. Tests were completed with the aid of SPSS (IBM Corp. Released 2013. IBM SPSS Statistics for Windows, Version 22.0. Armonk, NY: IBM Corp.) program.

\section{Results}

The fruit structure of 19 studied orchid taxa were investigated in terms of a variety of features like epidermal cell size, cell shape, surface ornamentation, presence of hairs or papillary structures, and inclusion of crystal or starch grains. On the valves of $S$. spiralis species, secretory hairs of a variety of sizes were identified. However, hairs were not encountered in the other taxa.

Additionally, the epidermal cell margins were unclear in S. spiralis and there was no surface ornamentation. In other taxa, ornamentation was longitudinal, transversal or in both directions, with striate or undulate. However, SEM photographs of the fruit surface of $N$. tridentata show reticulate pattern and accumulations similar to secretions on the surface. Similar accumulations were present in $S$. satyrioides (Figure 1, Table 3).

According to correlation analysis results applied with the aim of identifying the correlation between fruit structural character and ecological needs or habitat preferences of taxa, there was a positive correlation between fruit surface ornamentation and habitat preferences (Table 2).
Table 2. Correlation between structural features and ecological or habitat preferences.

\begin{tabular}{|c|c|c|c|c|}
\hline \multicolumn{5}{|c|}{ Correlations } \\
\hline & & & Elevation & Habitat \\
\hline & \multirow{2}{*}{$\begin{array}{l}\text { Epidermal cell } \\
\text { shape }\end{array}$} & Correlation Coefficient & .126 & .011 \\
\hline & & Sig. & .607 & .966 \\
\hline & \multirow{2}{*}{ Ornamentation } & Correlation Coefficient & .296 & $.654^{* * *}$ \\
\hline & & Sig. & .218 & .002 \\
\hline & \multirow{2}{*}{$\begin{array}{l}\text { Ornamentation } \\
\text { direction }\end{array}$} & Correlation Coefficient & .094 & .364 \\
\hline & & Sig. & .701 & .126 \\
\hline & \multirow{2}{*}{$\begin{array}{l}\text { Surface } \\
\text { secretion }\end{array}$} & Correlation Coefficient & -.393 & .067 \\
\hline & & Sig. & .096 & .786 \\
\hline & \multirow{2}{*}{ Hair } & Correlation Coefficient & -.270 & .046 \\
\hline & & Sig. & .264 & .852 \\
\hline & \multirow{2}{*}{$\begin{array}{l}\text { Papillary } \\
\text { structure }\end{array}$} & Correlation Coefficient & -.270 & -.391 \\
\hline & & Sig. & .264 & .098 \\
\hline & \multirow{2}{*}{ Crystal } & Correlation Coefficient & -.071 & .374 \\
\hline & & Sig. & .779 & .126 \\
\hline & \multirow{2}{*}{ Starch } & Correlation Coefficient & -.303 & .183 \\
\hline & & Sig. & .222 & .468 \\
\hline \multirow{6}{*}{ 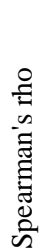 } & \multirow{2}{*}{ Placentha } & Correlation Coefficient & -.024 & -.248 \\
\hline & & Sig. & .924 & .322 \\
\hline & \multirow{2}{*}{ Elevation } & Correlation Coefficient & 1.000 & .192 \\
\hline & & Sig. & & .432 \\
\hline & \multirow{2}{*}{ Habitat } & Correlation Coefficient & .192 & 1.000 \\
\hline & & Sig. & .432 & \\
\hline & \multirow{2}{*}{$\begin{array}{l}\text { Epidermal cell } \\
\text { length }\end{array}$} & Pearson Correlation & -.354 & .300 \\
\hline & & Sig. & .150 & .227 \\
\hline & \multirow{2}{*}{$\begin{array}{l}\text { Epidermal cell } \\
\text { width }\end{array}$} & Pearson Correlation & -.107 & -.349 \\
\hline & & Sig. & .672 & .156 \\
\hline ర్ & \multirow{2}{*}{$\begin{array}{l}\text { Epidermal cell } \\
\text { heigth }\end{array}$} & Pearson Correlation & -.099 & -.159 \\
\hline$\stackrel{\bar{D}}{2}$ & & Sig. & .696 & .528 \\
\hline & \multicolumn{4}{|c|}{ *. Correlation is significant at the 0.05 level (2-tailed). } \\
\hline & \multicolumn{4}{|c|}{ **. Correlation is significant at the 0.01 level (2-tailed). } \\
\hline
\end{tabular}


Table 3. Qualitative characteristics and ecological preferences of taxa.

\begin{tabular}{|c|c|c|c|c|c|c|c|c|c|c|}
\hline $\begin{array}{l}\text { Taxa/ } \\
\text { characters }\end{array}$ & $\begin{array}{l}\text { Epidermal } \\
\text { cell shape }\end{array}$ & 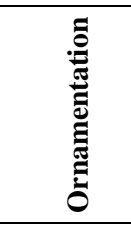 & 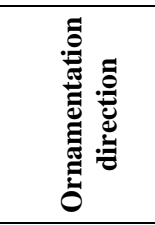 & 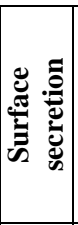 & Hair & 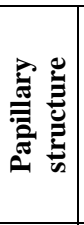 & Crystal & 总 & $\begin{array}{l}\text { Elevation } \\
\quad(\mathbf{m})\end{array}$ & Habitat \\
\hline A. laxiflora & $\begin{array}{l}\text { Isodiametric } \\
\text { to elongated }\end{array}$ & Striate & Transversal & - & - & + & Raphide & + & $0-500$ & Wet meadows \\
\hline $\begin{array}{l}\text { A. } \\
\text { papilionacea }\end{array}$ & $\begin{array}{l}\text { Isodiametric } \\
\text { to elongated }\end{array}$ & Striate & Vertical & - & - & - & Raphide & + & $1500-2000$ & $\begin{array}{l}\text { Meadows, Open areas, } \\
\text { Edges of forests }\end{array}$ \\
\hline $\begin{array}{l}\text { A. } \\
\text { pyramidalis }\end{array}$ & Elongated & Striate & $\begin{array}{l}\text { Double } \\
\text { direction }\end{array}$ & - & - & - & Raphide & +++ & $500-1000$ & $\begin{array}{l}\text { Meadows, Open areas, } \\
\text { Edges of forests }\end{array}$ \\
\hline C. viride & $\begin{array}{l}\text { Isodiametric } \\
\text { to elongated }\end{array}$ & Undulate & Transversal & - & - & - & Prismatic & + & $1000-1500$ & Meadows \\
\hline D. euxina & Isodiametric & Striate & Transversal & - & - & - & Raphide & + & $1500-2000$ & Wet meadows \\
\hline D. romana & Isodiametric & Striate & Vertical & - & - & - & Raphide & +++ & $500-1000$ & $\begin{array}{l}\text { Meadows, Open areas, } \\
\text { Edges of forests }\end{array}$ \\
\hline D. saccifera & $\begin{array}{l}\text { Isodiametric } \\
\text { to elongated }\end{array}$ & Undulate & $\begin{array}{c}\text { Double } \\
\text { direction }\end{array}$ & - & - & - & Raphide & + & $1500-2000$ & $\begin{array}{l}\text { Meadows, Open areas, } \\
\text { Edges of forests }\end{array}$ \\
\hline G. conopsea & $\begin{array}{l}\text { Isodiametric } \\
\text { to elongated }\end{array}$ & Undulate & Vertical & - & - & - & Raphide & + & $1500-2001$ & Meadows \\
\hline H. caprinum & Elongated & Undulate & $\begin{array}{c}\text { Double } \\
\text { direction }\end{array}$ & - & - & - & Raphide & +++ & $1500-2002$ & $\begin{array}{c}\text { Meadows, Open areas, } \\
\text { Edges of forests }\end{array}$ \\
\hline N. tridentata & Isodiametric & Reticulate & $\begin{array}{l}\text { Double } \\
\text { direction }\end{array}$ & + & - & - & Raphide & +++ & $0-500$ & Meadows \\
\hline O. apifera & $\begin{array}{l}\text { Isodiametric } \\
\text { to elongated }\end{array}$ & Striate & Vertical & - & - & - & Raphide & +++ & $0-500$ & Forest \\
\hline O. oestrifera & $\begin{array}{l}\text { Isodiametric } \\
\text { to elongated }\end{array}$ & Striate & Vertical & - & - & - & Raphide & + & $0-500$ & Forest \\
\hline O. mascula & $\begin{array}{l}\text { Isodiametric } \\
\text { to elongated }\end{array}$ & Striate & Transversal & - & - & - & Absent & +++ & $500-1000$ & $\begin{array}{c}\text { Meadows, Open areas, } \\
\text { Edges of forests }\end{array}$ \\
\hline O. pallens & Isodiametric & Undulate & $\begin{array}{l}\text { Double } \\
\text { direction }\end{array}$ & - & - & - & Raphide & + & $1000-1500$ & $\begin{array}{l}\text { Meadows, Open areas, } \\
\text { Edges of forests }\end{array}$ \\
\hline O. purpurea & Elongated & Undulate & Vertical & - & - & - & Raphide & + & $500-1000$ & $\begin{array}{l}\text { Meadows, Open areas, } \\
\text { Edges of forests }\end{array}$ \\
\hline P. clorantha & $\begin{array}{l}\text { Isodiametric } \\
\text { to elongated }\end{array}$ & Striate & Vertical & - & - & - & Raphide & +++ & $500-1000$ & Forest \\
\hline S. orientalis & $\begin{array}{l}\text { Isodiametric } \\
\text { to elongated }\end{array}$ & Undulate & $\begin{array}{l}\text { Double } \\
\text { direction }\end{array}$ & - & - & - & Prismatic & +++ & $0-500$ & Meadows \\
\hline $\begin{array}{l}\text { S. } \\
\text { satyrioides }\end{array}$ & $\begin{array}{l}\text { Isodiametric } \\
\text { to elongated }\end{array}$ & Striate & Vertical & + & - & - & Raphide & + & $0-500$ & Forest \\
\hline $\begin{array}{l}\text { Spiranthes } \\
\text { spiralis }\end{array}$ & Isodiametric & Absent & Transversal & - & $\begin{array}{c}\text { Secretory } \\
\text { hair }\end{array}$ & - & & & $0-500$ & $\begin{array}{l}\text { Meadows, Open areas, } \\
\text { Edges of forests }\end{array}$ \\
\hline
\end{tabular}

Epidermal cells are isodiametric or elongated, and are pentagonal or hexagonal. In the cross-sections of $A$. laxiflora, elongated papillary structures is notable between the epidermal cells. Also, starch grains or crystals are clear with density on the mesocarp varying from species to species. While fruits are commonly observed to have raphide bundles, prismatic crystals found in species like $S$. orientalis and $C$. viride. Vascular bundles are collateral. In all taxa, the placenta is characterized by a single row cells with large nuclei and dense cytoplasm (Figure 2, Table 2).

Circular graphs were used with the aim of comparing the mean epidermal cell sizes between taxa (Figure 3). Accordingly, among the three features, the largest epidermal cells were found in $O$. mascula.

However, the cell length for D. euxina, cell width for $C$. viride and cell height for $G$. conopsea had smallest values measured.

Canonical discrimination analysis was used with the aim of determining the degree of accuracy of groupings according to fruit structural features and which feature was more effective in this grouping. Figure 4 shows the distribution of taxa based on the first two components. Accordingly, at genus level, taxa were accurately grouped with $94.4 \%$ success rate.

The most effective characters in canonical discrimination analysis were the morphometric features of epidermal cells like length, width and height. Additionally, the presence and variety of crystal in the tissue or habitat preferences of taxa came to the fore during taxon grouping (Table 4). 


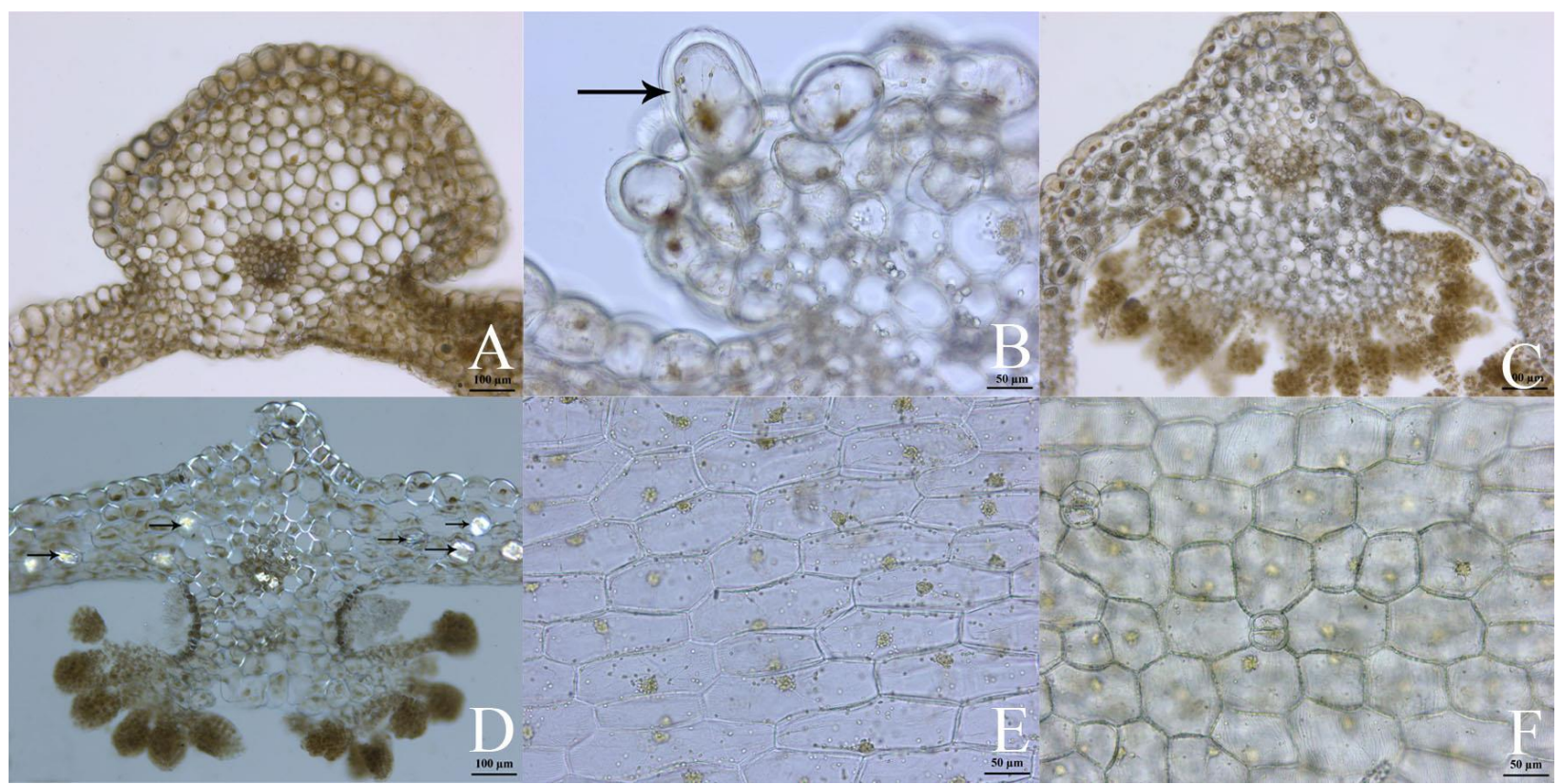

Figure 2. Light microscope image of pericarp in transverse and surface sections: (A) O. purpurea, (B) A. laxiflora, (C) P. chlorantha, (D) D. saccifera, (E) A. papilionacea, (F) N. tridentata.

\section{Discussions}

In the literature, hair with a variety of sizes and structures were reported on the vegetative and generative organs of orchids. Mainly researched for floral structures, these secretory hairs are emphasized to have functions in attracting pollinators acting as osmophore or nectarium due to secretions like mucilage, lipophilic compounds, pectic acid or phenolic compounds (Stpiczyńska and
Davies, 2009; Nunes et al., 2014, 2015). In the literature, endocarpic hairs are mentioned in epiphytic species and it was emphasized that this type of trichome was only found on epiphytes (Beer, 1857; Horowitz, 1901-1902). As seen in our anatomical investigations, the lack of these types of structure in terrestrial species supports this view.
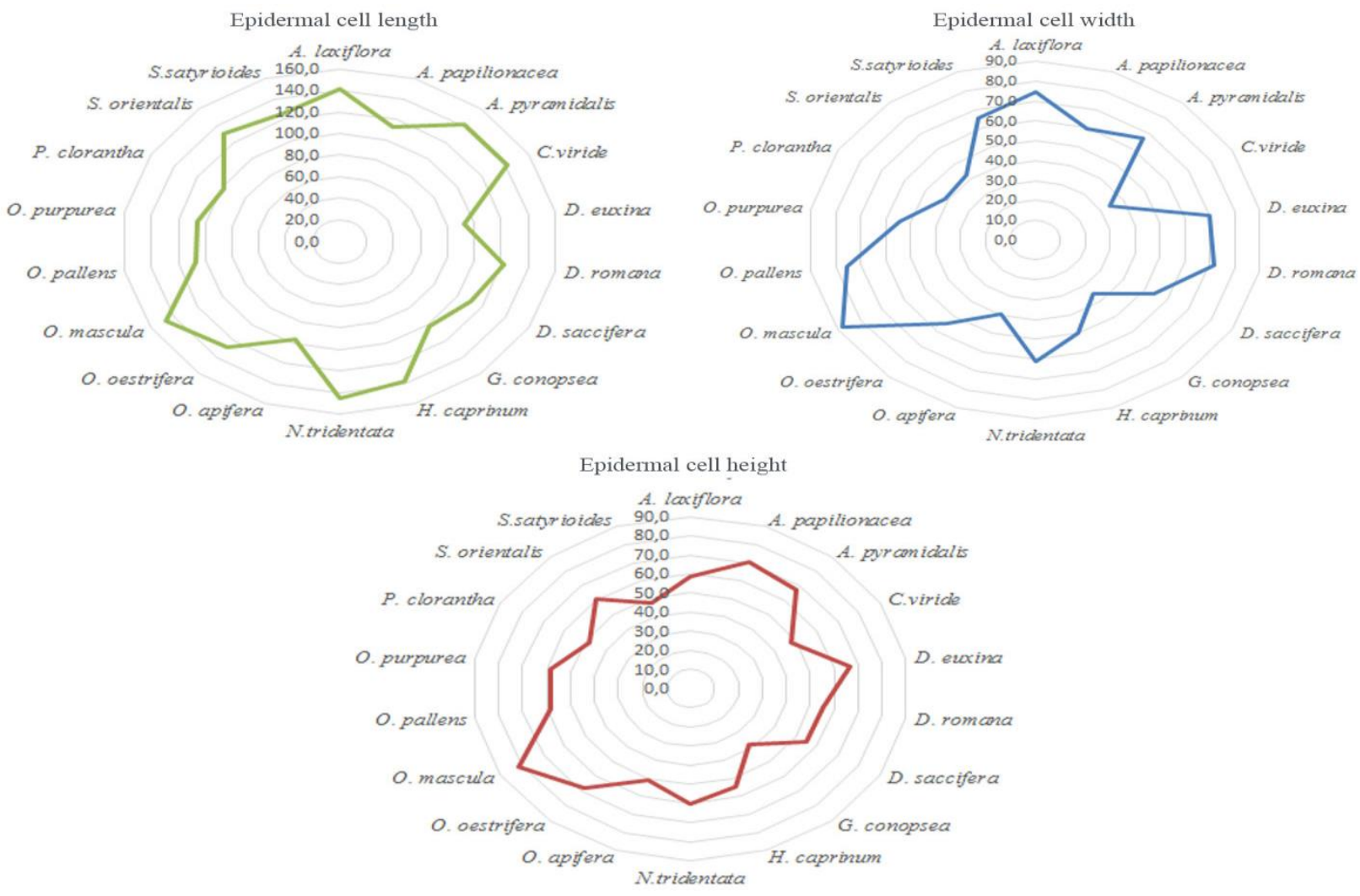

Figure 3. Circular plots of quantitative epidermal features. 
Correlation analysis results mean that in habitats with higher humidity rates, the cuticle layer or secondary wall thickness reduces on the fruit surface and indicates that the surface ornamentation may be related to ecological adaptation rather than being a differentiating character for species.

As emphasized in previous research, though orchid fruit display homogeneous structure in terms of basic structural features, there is variety in terms of features like the shape, size and content of pericarp cells (Mayer et al., 2011). Though studies about orchid fruit have noted different features for identification of taxa, micromorphological and morphometric features have been ignored. For example, Prillieux (1857) identified 7 different fruit according to dehiscence type and stated that this variety may be useful to characterize species according to some criteria like apically fused vs. free, recurving valves, and valve number. Horowitz (19011902) in a study of many orchids classified taxa according to number and distribution of vascular bundles.

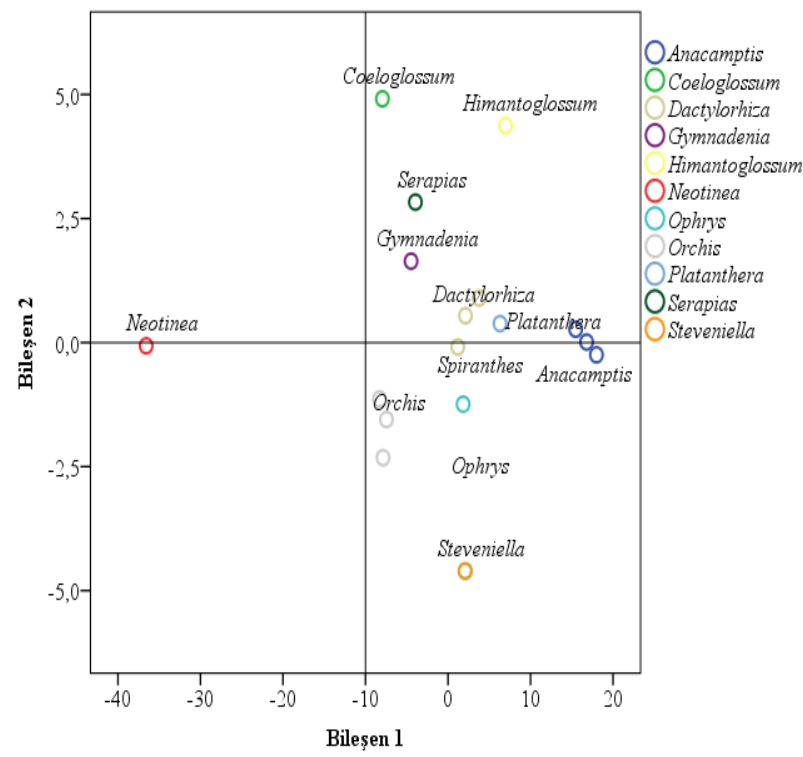

Figure 4. Distribution of genera on canonical discrimination components.
In morphometrical investigation, the cell sizes for $D$. euxina, $C$. viride and $G$. conopsea had smallest values. A study using molecular markers like ITS proved the close phylogenetic relationships between these three taxa (Shipunov et al., 2004). Moreover, Bateman et al. (1997) included the $C$. viride $(D$. viridis) species in the Dactylorhiza species and this new classification has been adopted by many researchers. In our study, this common morphometric feature in the pericarp epidermal cells of the three taxa support this view.

In this study, though structural character has low differentiation power for Ophrys taxa, discrimination analysis was found that fruit morphometric features have high rates of success for differentiation of other taxa. According to this finding, the pericarp features of orchidoid species may be effective for classification of genus and upper categories.

Table 4. Characters associated with discrimination components.

\begin{tabular}{|l|l|l|}
\hline \multirow{2}{*}{ Characters } & \multicolumn{2}{l|}{ Function } \\
\cline { 2 - 3 } & 1 & 2 \\
\hline Epidermal cell length & .024 & $-.752^{*}$ \\
\hline Epidermal cell widt & .271 & $-.587^{*}$ \\
\hline Epidermal cell heigth & .199 & $-.568^{*}$ \\
\hline Epidermal cell shape & .031 & .051 \\
\hline Papillae & .021 & .000 \\
\hline Starch & -.009 & .056 \\
\hline Habitat & -.479 & -.147 \\
\hline Ornamentation direction & -.011 & .024 \\
\hline Ornamentation & -.085 & .243 \\
\hline Crystal & -.005 & .301 \\
\hline Elevation & .018 & .229 \\
\hline Pooled within-groups correlations between discriminating \\
variables and standardized canonical discriminant functions \\
$\begin{array}{l}\text { Variables ordered by absolute size of correlation within } \\
\text { function. }\end{array}$ *. Largest absolute correlation between each variable and any \\
discriminant function
\end{tabular}

\section{Acknowledgments}

This research was funded by a grant from the Scientific and Technological Research Council of Turkey (114Z702).

\section{References}

Akbulut MK, Şenel, G (2016). The seeds micromorphology and morphometry of certain Dactylorhiza (Orchidaceae) species distributed in Turkey. Rendiconti Lincei 27: 679-686.

Anton S, Kaminska M, Stpiczyńska M (2012). Comparative structure of the osmophores in the flower of Stanhopea graveolens Lindley and Cycnoches chlorochilon Klotzsch (Orchidaceae). Acta Agrobotanica 65: 11-22.

Arditti J, Ghani AKA (2000). Numerical and physical properties of orchid seeds and their biological implications. New Phytologist 145: 367-421.

Arditti J (1977). Orchid biology, reviews and perspectives. Ithaca and London: Cornell University Press.

Barthlott W, Große-Veldmann B, Korotkova N (2014). Orchid seed diversity. Englera 32: 1-245.

Bateman RM, Hollingsworth PM, Preston J, Yi-Bo L, Pridgeon AM, Chase MW (2003). Molecular phylogenetics and evolution of Orchidinae and selected Habenariinae (Orchidaceae). Botanical journal of the Linnean Society 142(1): 1-40.

Bateman RM, Pridgeon AM, Chase MW (1997). Phylogenetics of subtribe Orchidinae (Orchidoideae, Orchidaceae) based on nuclear its sequences. 2. Infrageneric relationships and reclassification to achieve monophyly of Orchis sensu stricto. Lindleyana 12: 113-141.

Beer JG (1857). Über das Vorkommen eines schleuderorganes in den früchten verschiedener orchideen. Sitzungsber. Kaiserl. Akad. Wiss., Math.-Naturwiss. 24: 23-28.

Bektaş E, Cüce M, Sökmen (2013). A In vitro germination, protocorm formation, and plantlet development of Orchis coriophora (Orchidaceae), a naturally growing orchid species in Turkey. Turkish Journal of Botany 37(2): 336-342. 
Bell AK, Roberts DL, Hawkins JA, Rudall PJ, Box MS, Bateman RM (2009). Comparative micromorphology of nectariferous and nectarless labellar spurs in selected clades of subtribe Orchidinae (Orchidaceae). Botanical journal of the Linnean Society 160: 369-387.

Brown R (1831). Observations on the organs and mode of fecundation in Orchideae and Asclepiadeae, London: Richard Taylor.

Chase MW, Cameron KM, Freudenstein JV, Pridgeon AM, Salazar G, Van den Berg C, Schuiteman A (2015). An updated classification of Orchidaceae. Botanical journal of the Linnean Society 177: 151-174.

Chemisquy MA, Prevosti FJ, Morrone O (2009). Seed morphology in the tribe Chloraeeae (Orchidaceae): Combining traditional and geometric morphometrics. Botanical journal of the Linnean Society 160: 171-183.

Chen J, Wang H, Guo, SX (2012). Isolation and identification of endophytic and mycorrhizal fungi from seeds and roots of Dendrobium (Orchidaceae). Mycorrhiza 22: 297-307.

Cozzolino S, Widmer A (2005). Orchid diversity: An evolutionary consequence of deception. Trends in Ecology \& Evolution 20: 487-494.

Davis PH, Davis P (1982). Flora of Turkey and the East Aegean Islands, Vol 8. Edinburgh: Edinburgh University Press.

Dressler RL (1993). Phylogeny and classification of the orchid family. Cambridge: Cambridge University Press.

Gamarra R, Dorda E, Scrugli A, Galán P, Ortúñez E (2007). Seed micromorphology in the genus Neotinea Rchb f (Orchidaceae, Orchidinae). Botanical journal of the Linnean Society 153: 133-140.

Gamarra R, Ortúñez E, Cela PG, Guadaño V (2012). Anacamptis versus Orchis (Orchidaceae): Seed micromorphology and its taxonomic significance. Plant Systematics and Evolution 298(3): 597-607.

Gamarra R, Ortúñez E, Cela PG, Merencio Á (2018). Seed micromorphology of Orchidaceae in the Gulf of Guinea (West Tropical Africa). Plant Systematics and Evolution 304(5): 665-677.

Güner A, Aslan S, Ekim T, Vural M, Babaç MT (2012). Türkiye Bitkileri Listesi, Damarlı Bitkiler. İstanbul: Nezahat Gökyiğit Botanik Bahçesi ve Flora Araştırmaları Derneği Yayını.

Horowitz A (1901-1902). Ueber den anatomischen Bau und das Aufspringen der Orchideen früchte. Beihefte zum Botanischen Cen-tralblatt 11: 486-521.

Lee YI, Lee N, Yeung EC, Chung MC (2005). Embryo development of Cypripedium formosanum in relation to seed germination in vitro. Journal American Society for Horticultural Science 130: 752-753.

Lee YI, Lu FL, Yeung EC, Chung MC (2007). Developmental change in endogenous abscisic acid concentrations and asymbiotic seed germination of a terrestrial orchid, Calanthe tricarinata Lindl. Journal American Society for Horticultural Science 132: 246-252.

Mayer JLS, Carmello-Guerreiro SM, Appezzato-da-Glória B (2011). Anatomical development of the pericarp and seed of Oncidium flexuosum Sims (Orchidaceae). Flora 206: 601-609.

Molvray M, Chase M (1999). Seed Morphology In: Pridgeon AM, Cribb PJ, Chase MW, Rasmussen FN (eds) Genera Orchidacearum, Vol 1: General introduction, Apastosiodeae, Cypripedioideae. Oxford: Oxford University Press.

Nunes ELP, Smidt EC, Stützel T, Coan AI (2015). Comparative floral micromorphology and anatomy of species of Bulbophyllum section Napelli (Orchidaceae), a Neotropical section widely distributed in forest habitats. Botanical Journal of the Linnean Society 177: 378-394.

Nunes EL, Smidt EC, Stützel T, Coan AI (2014). What do floral anatomy and micromorphology tell us about Neotropical Bulbophyllum section Didactyle (Orchidaceae: Bulbophyllinae)? Botanical Journal of the Linnean Society 175(3): 438452.

Payer JB (1857). Traité d'organogènie vegetale comparée la fleur. Paris: Victor Masson.

Prillieux E (1857). Observations sur la déhiscence du fruit des Orchidées. Bulletin de la Société Botanique de France 4: 803-809.

Rasmussen FN, Johansen B (2006). Carpology of orchids. Selbyana 27(1): 44-53.

Schiestl F (2005). On the success of a swindle: Pollination by deception in orchids. Naturwissenschaften 92: 255-264.

Sezik E (1984). Orkidelerimiz, Türkiye'nin orkideleri, İstanbul: Sandoz Kültür Yayınları.

Shipunov AB, Fay MF, Pillon Y, Bateman RM, Chase MW (2004). Dactylorhiza (Orchidaceae) in European Russia: Combined molecular and morphological analysis. American Journal of Botany 91(9): 1419-1426.

Stpiczyńska M, Davies KL (2009). Floral, resin-secreting trichomes in Maxillaria dichroma Rolfe (Orchidaceae: Maxillariinae). Acta Agrobotanica 62: 43-51.

Stpiczyńska M (2003). Nectar resorption in the spur of Platanthera chlorantha Custer (Rchb) Orchidaceae: Structural and microautoradiographic study. Plant Systematics and Evolution 238(3): 119-126.

Şeker ŞS, Şenel G (2017). Comparative seed micromorphology and morphometry of some orchid species (Orchidaceae) belong to the related Anacamptis, Orchis and Neotinea genera. Biologia 72(1): 14-23.

Tesitelová T, Tesitel J, Jersakova J, Ríhová G, Selosse MA (2012). Symbiotic germination capability of four Epipactis species (Orchidaceae) is broader than expected from adult ecology. American Journal of Botany 99(6): 1020-1032.

The Plant List (2018). http://www.theplantlist.org / [accessed 19 June 2019].

Van Tieghem PEL (1871). Recherches sur la structure du pistil et sur l'anatomie comparée de la fleur. Paris: Imprimerie Nationale.

Vereecken NJ (2009). Deceptive behaviour in plants Pollination by sexual deception in orchids: A host-parasite perspective. In Baluska F (ed) Plant-environment interactions, signaling and communication in plants, from sensory plant biology to active plantbehaviour Germany. Berlin: Springer-Verlag. 